\title{
Sodankylä manual snow survey program
}

\author{
Leena Leppänen ${ }^{1}$, Anna Kontu ${ }^{1}$, Henna-Reetta Hannula ${ }^{1}$, Heidi Sjöblom ${ }^{2}$, and Jouni Pulliainen ${ }^{1}$ \\ ${ }^{1}$ Finnish Meteorological Institute, Arctic Research, Sodankylä, Finland \\ ${ }^{2}$ Finnish Environment Institute, Helsinki, Finland
}

Correspondence to: Leena Leppänen (leena.leppanen@fmi.fi)

Received: 27 November 2015 - Published in Geosci. Instrum. Method. Data Syst. Discuss.: 10 December 2015

Revised: 19 April 2016 - Accepted: 25 April 2016 - Published: 30 May 2016

\begin{abstract}
The manual snow survey program of the Arctic Research Centre of the Finnish Meteorological Institute (FMI-ARC) consists of numerous observations of natural seasonal taiga snowpack in Sodankylä, northern Finland. The easily accessible measurement areas represent the typical forest and soil types in the boreal forest zone. Systematic snow measurements began in 1909 with snow depth (HS) and snow water equivalent (SWE). In 2006 the manual snow survey program expanded to cover snow macro- and microstructure from regular snow pits at several sites using both traditional and novel measurement techniques. Present-day snow pit measurements include observations of HS, SWE, temperature, density, stratigraphy, grain size, specific surface area (SSA) and liquid water content (LWC). Regular snow pit measurements are performed weekly during the snow season. Extensive time series of manual snow measurements are important for the monitoring of temporal and spatial changes in seasonal snowpack. This snow survey program is an excellent base for the future research of snow properties.
\end{abstract}

\section{Introduction}

Snow is an important parameter in meteorological and climatological research because of its high albedo $(0.80-0.90$ for fresh snow), thermal insulation properties and water equivalent (Groisman et al., 1994; Cohen and Rind, 1991). Snow reflects most of the upcoming radiation back to space and reduces significantly the amount of radiation absorbed by the ground and atmosphere. This surface-albedo feedback (SAF) is a positive feedback mechanism and has potentially a major effect in global warming (Hall and Qu, 2006). Snow is a good thermal insulator. Snow cover slows down soil freezing and affects the depth of ground frost (Hardy et al., 2001). Snow cover stores the solid wintertime precipitation and releases it to water systems during the relative short snowmelt in spring. Therefore, snow has a large effect on the global water cycle and ecology, in addition to social aspects, as a water reservoir (van Dijk et al., 2014; Barnett et al., 2005).

Moreover, seasonal snow cover can be used as a proxy for monitoring the effects of climate change (HernándezHenríquez at al., 2015). The most important observed snow cover parameters are snow water equivalent (SWE), snow extent (SE) and snow depth (HS). In many applications, remote sensing is used for global daily observations. However, automatic weather station observations and manual measurements still have an important role in snow monitoring, especially in numerical weather prediction (NWP) systems (e.g. de Rosnay et al., 2014), hydrological monitoring and climate models.

Many snow properties can be measured automatically, but manual measurements are still vital for exact observations of snow structure. Snow microstructure is defined with such grain-related properties as size, shape, orientation and bonding (Fierz et al., 2009). Snowpack consists of horizontal layers having varying micro- and macrostructural properties (Colbeck, 1991). Grain metamorphism changes snow microstructure, and is driven mainly by varying temperature differences between air and ground, and the pressure of the upper snowpack (Colbeck, 1982). Therefore, vertical changes of macrostructural parameters, such as temperature and density, are related to the evolution of snow microstructure. However, the structure of snowpack is very complex and spatial variations are large even on a small scale (Rutter et al., 2014; Derksen et al., 2009). Therefore, manual observations of snow macro- and microstructure have an important role in the monitoring of temporal evolution and spatial variations of snowpack. 
This paper introduces the manual snow survey program, the long-standing and present-day manual observations of natural seasonal snowpack, of the Arctic Research Centre of the Finnish Meteorological Institute (FMI-ARC). Measurements started in 1909 with HS and SWE observations. The extent of manual snow measurements has constantly grown. In 2006 regular snow pit measurements of snow macro- and microstructure began, at first on a smaller scale and later with additional modern measurement techniques. The Sodankylä manual snow survey program aims to study the spatial and temporal variability of snowpack in varying environmental conditions typical to the boreal forest zone, including pine and spruce forests, open bogs and lake ice (e.g. Hannula et al., 2016; Lemmetyinen et al., 2015; Kontu et al., 2014; Kontu and Pulliainen, 2010). The data set is also important as a reference for the development of remote sensing instruments (Lemmetyinen et al., 2016b) and interpretation algorithms and models (Leinss et al., 2015; Schwank et al., 2014; Rautiainen et al., 2014).

In addition to Sodankylä, regular manual snow measurements are made in few places in Europe. Two measurement sites, Weissfluhjoch in Switzerland (Marty and Meister, 2012) and Col de Porte in France (Morin et al., 2012), are presented in the literature. Manual snow measurements have been made at the Weissfluhjoch site since 1936. Regular measurements include daily snow depth and depth of new snow, bi-weekly ram sonde measurements, definition of layers, grain size, grain type, hardness, temperature profile and SWE profile (Meister, 2009). Measurements at the Col de Porte site were made in 1993-2011. Weekly snow pit measurements included penetration resistance with ram sonde, temperature, density, snow type, LWC and grain size (Morin et al., 2012).

Both Weissfluhjoch and Col de Porte are located in the Alps in central Europe, at altitudes of 2540 and $1325 \mathrm{~m}$, respectively. The environment of the Sodankylä measurement site (altitude $185 \mathrm{~m}$ ) is very different from the Alpine sites. At the Alpine sites, the duration of daylight is longer and the Sun's elevation angle is higher than in Sodankylä, especially during polar night. Thus, increased solar radiation and higher air temperature lead to more frequent melting and refreezing events and a shorter snow cover period. The unforested Weissfluhjoch site has additional effects of wind and slope compared to Col de Porte and Sodankylä sites. Additionally, the FMI-ARC data set includes measurements in several sites in Sodankylä with different land cover types including pine forest on mineral soil, open peat bog and lake ice, while the Weissfluhjoch site has gravel cover and the Col de Porte site has grass cover. However, both of these sites have a longer time series of snow pit measurements than the Sodankylä site. All of these sites also have automatic snow and weather observations.

The measurements of the Sodankylä manual snow survey program have been exploited in several studies. Leppänen et al. (2015) compared manual snow microstructure measure- ments to a snow model. Snow pit data were used in the development and validation of a new method to measure SWE by differential interferometry (Leinss et al., 2015) and a new ground-snow radiative transfer model at L-band (Schwank et al., 2014). They were also applied in the monitoring of soil processes (Rautiainen et al., 2012), in the retrieval of snow density and ground permittivity from L-band radiometry (Lemmetyinen et al., 2016a) and in the study of seasonally and spatially varying snow cover brightness temperature (Lemmetyinen et al., 2015). Cheng et al. (2014) applied lake ice measurements to validate buoy-based measurements of lake snow and ice thicknesses. Moreover, snow pit and lake ice measurements were applied by Kontu et al. (2014) to study the effect of snow and ice-covered lakes and wetlands to microwave brightness temperature simulation accuracy. In addition, Kontu and Pulliainen (2010) used the snow pit measurements to simulate a time series of brightness temperatures and compared the results to spaceborne microwave radiometer measurements. Salminen et al. (2009) studied the reflectance spectra of snow-covered ground in different snow conditions in order to assess the feasibility of satellite sensors to mapping of snow-covered area in boreal forests. Meinander et al. (2008) found a diurnal decrease in snow UV albedo, and explained this by daily metamorphosis of the snow surface.

The measurement sites as well as the measurement techniques, instruments and error sources of each parameter are described in Sect. 2. Section 3 presents the data sets, lists the measurements and sites in each set and describes the measurement protocols. In addition, some examples of the data are shown. Section 4 summarises the data availability, and Sect. 5 is the summary of the paper.

\section{Measurement sites and methods}

\subsection{FMI-ARC station}

Sodankylä is located above the Arctic Circle in the boreal forest zone, and its snow conditions fall in the taiga class (Sturm and Holmgren, 1995). The FMI-ARC station is located in $67.368^{\circ} \mathrm{N}, 26.633^{\circ} \mathrm{E}, 7 \mathrm{~km}$ south of the Sodankylä town centre. A map of the research station area and surroundings, including the manual snow measurement sites, is shown in Fig. 1. The station is a member of the WMO (World Meteorological Organization) Global Cryosphere Watch network.

The manual snow measurement sites, with short listings of their automatic measurements, are presented in more detail in this section. FMI-ARC also hosts other snow-related automatic measurement sites, which are presented in more detail in this special issue, such as the micrometeorological mast (Kangas et al., 2016), the road weather station (Sukuvaara et al., 2016), the UV measurement field (Meinander et al., 2016; Mäkelä et al., 2016), the distributed soil moisture and frost stations (Ikonen et al., 2015) and the optical lab- 
oratory (Lakkala et al., 2016). In addition, a 7-year data set for driving and evaluating snow models has been collected by Essery et al. (2016).

In the $100 \mathrm{~km} \times 100 \mathrm{~km}$ area around FMI-ARC (Fig. 1a, referred to as "the Sodankylä area" later on), the most common land cover types in Corine Land Cover 2006 (Törmä et al., 2008) are coniferous forest on mineral soil (32\%), open peat bogs $(23 \%)$, and coniferous forest on peatland $(8 \%)$. The FMI-ARC (Fig. 1c) station area covers coniferous forests and open areas on mineral soil, as well as open peat bog.

Based on the 30-year (1981-2010) meteorological statistics (Pirinen et al., 2012), the first snow typically falls in Sodankylä in October, while snow melt-off takes place in mid-May. The snow maximum of $79 \mathrm{~cm}$ in average occurs in late March. Monthly mean air temperature is below $0{ }^{\circ} \mathrm{C}$ from November to April, and the yearly mean temperature is $-0.4{ }^{\circ} \mathrm{C}$. Measured air temperature varies between $-49.5^{\circ} \mathrm{C}$ (January 1999) and $+30.9^{\circ} \mathrm{C}$ (July 1988). Mean yearly total precipitation is $527 \mathrm{~mm}$ and monthly mean wind speed above treetops is between 2.5 and $2.9 \mathrm{~m} \mathrm{~s}^{-1}$.

In addition to the 30-year wind speed averages, a wind sensor (WAA25 by Vaisala, Helsinki, Finland) at $18 \mathrm{~m}$ height (above treetops) at the micrometeorological mast site about $170 \mathrm{~m}$ from the intensive observation area (IOA) area measured an average wind speed for 10-year period (2006-2015) of $2.2 \mathrm{~m} \mathrm{~s}^{-1}$ with a standard deviation of $1.26 \mathrm{~m} \mathrm{~s}^{-1}$. Another sensor (Ultrasonic Anemometer 2-D by Thies Clima, Göttingen, Germany) at $1.5 \mathrm{~m}$ height in a forest opening about $500 \mathrm{~m}$ from the IOA area measured a 2-year (2014-2015) mean value during the snow season from mid-September to mid-May each year of $1.17 \mathrm{~m} \mathrm{~s}^{-1}$ with a standard deviation of $0.56 \mathrm{~m} \mathrm{~s}^{-1}$. These measurements highlight the very low wind speeds in the forested areas and the forest openings of the FMI-ARC station.

Synoptic weather observations have been made in Sodankylä since 1908 (Tietäväinen et al., 2010), first in the town centre and since 1913 at the current research station area. Today two institutes share the station: Sodankylä Geophysical Observatory (SGO), which was established in 1913 as Magnetic Observatory and is presently part of the Oulu University, and FMI observatory, which was established in 1949 and continues the meteorological data records at the site.

\subsection{Measurement sites}

This section describes the manual measurement sites in alphabetical order. Maps with locations of all the measurement sites are in Fig. 1. Photos from most of the measurement sites are in Fig. 2.

\subsubsection{Airport}

The airport site is an open area on mineral soil located on the premises of Sodankylä airport about $3 \mathrm{~km}$ north of FMI-ARC (a)

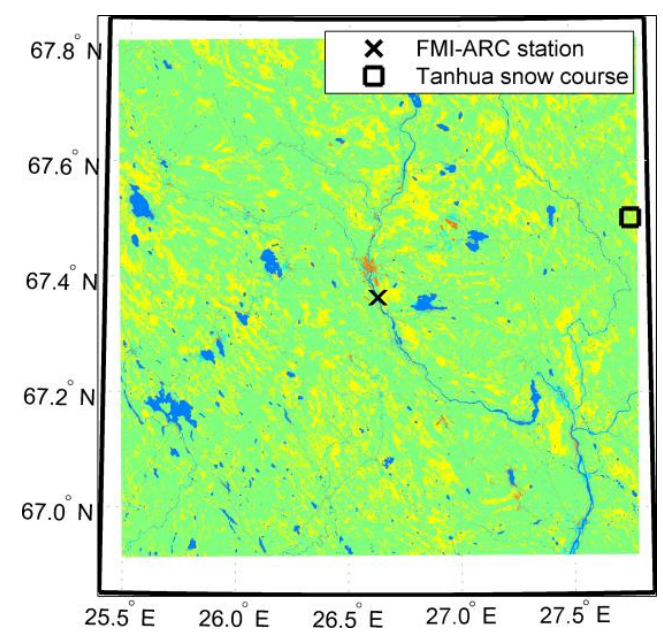

(b)

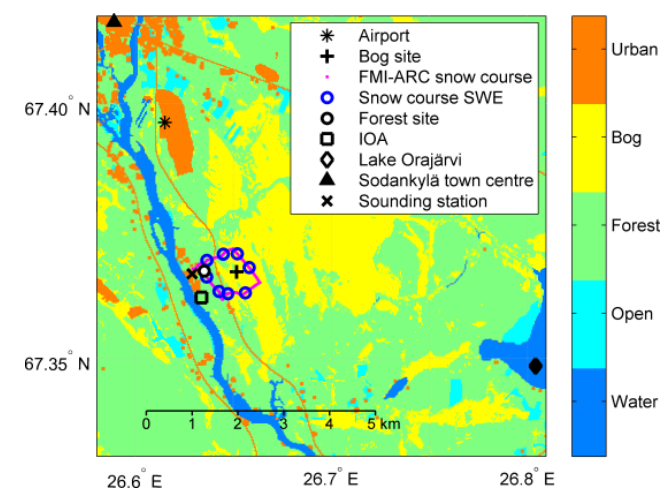

(c)

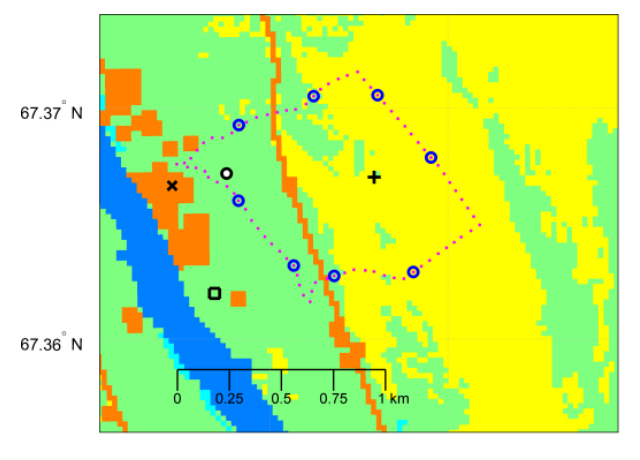

$26.62^{\circ} \mathrm{E} \quad 26.64^{\circ} \mathrm{E} \quad 26.66^{\circ} \mathrm{E} \quad 26.68^{\circ} \mathrm{E}$

Figure 1. Maps of (a) the $100 \mathrm{~km} \times 100 \mathrm{~km}$ area around FMI-ARC station, (b) the FMI-ARC station and surroundings, and (c) a closeup of the FMI-ARC station area with the manual measurement sites. In (b) and (c), individual measurement locations of the snow course are marked. The legend and colour scale of maps (a) and (c) are the same as in (b). All the maps are in orthographic projection. The background of the maps is Corine Land Cover 2006 aggregated into five general classes. 
(a)

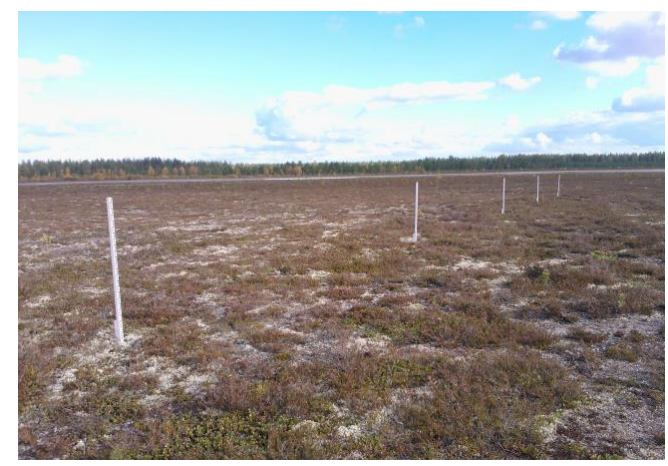

(b)

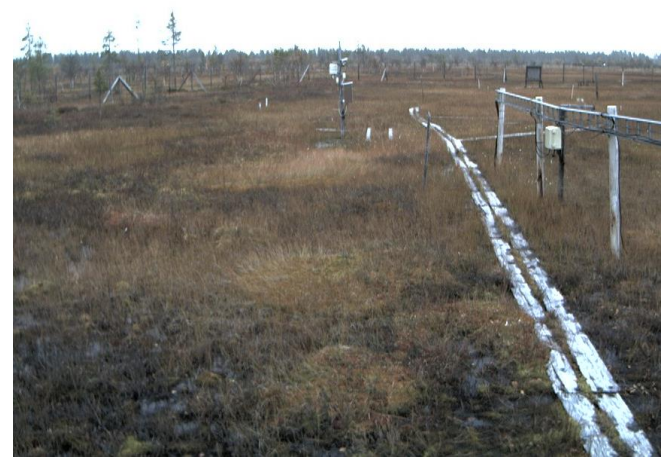

(c)

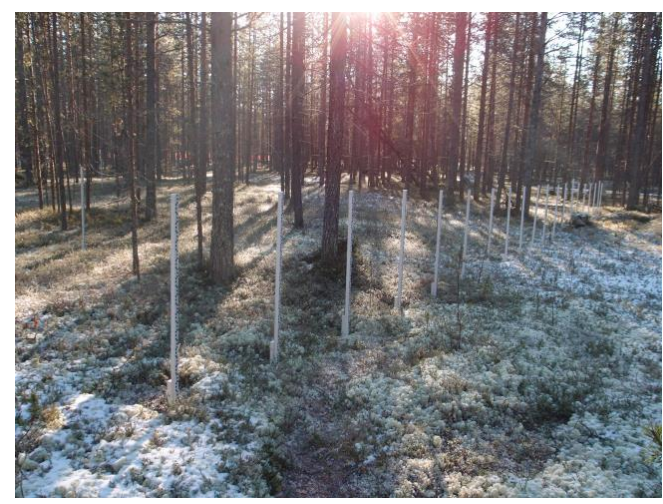

(d)
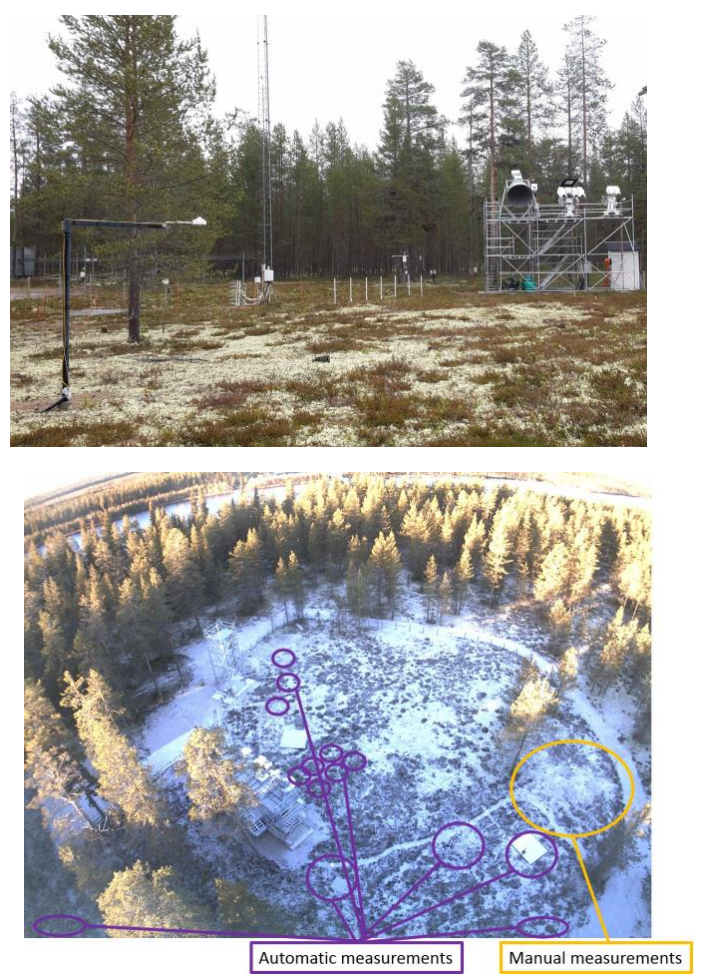

(e)

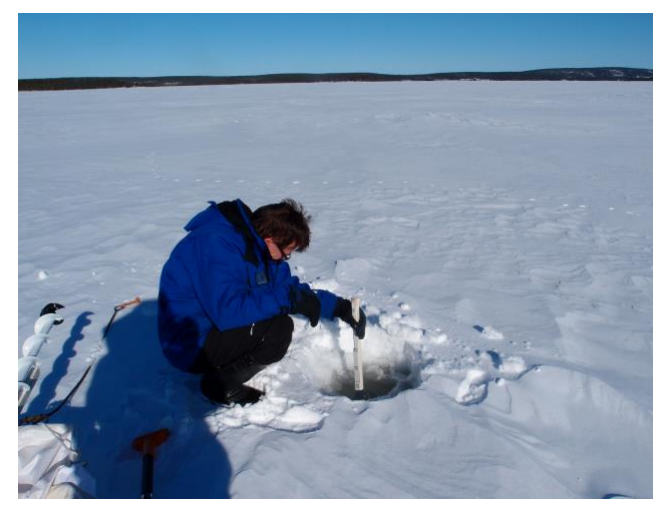

Figure 2. Snow measurement sites: (a) airport, (b) bog site, (c) forest site, (d) IOA, (e) Lake Orajärvi.

(* in Fig. 1b). The vegetation on the area is heather, crowberry and lichen, which are sparse and typically $10-15 \mathrm{~cm}$ high (Fig. 2a). There are no automatic measurements on this site. HS (from fixed stakes) and SWE have been measured every 5 days in January and March since 1972. The site was chosen for measurements since it is one of the few large open areas on mineral soil closed from public in the vicinity of FMI-ARC.

\subsubsection{Bog site}

Open peat bogs are the second most common land cover type in the Sodankylä area with a coverage of $23 \%$ (Corine Land Cover 2006). The manual snow measurement site was established in 2009 on an area that already hosted automatic UV measurements. The bog site (+ in Fig. 1b, c) is located about $1 \mathrm{~km}$ northeast from the main snow measurement site IOA. The bog site is a moss-covered peat bog with low vegetation (grass and twigs) as shown in Fig. 2b. The water level varies 
due to precipitation and time of year; every spring during and after snowmelt the bog site is completely submerged, but the autumn conditions might range from completely submerged to completely dry. Typically snow accumulates over a smooth ice layer, which is infrequently penetrated by low vegetation. Wind redistributes snow and levels the snowpack surface. With direct sunlight it adds evaporation from the snowpack and hard crust layers are formed easier to the snowpack surface than in forested areas.

Automatic observations of HS (SR50 by Campbell Scientific Inc., Logan, Utah, USA), SWE (Gamma Water Instrument by Astrock, Sodankylä, Finland), broadband albedo (CMA11 by Kipp \& Zonen, Delft, Netherlands), snow temperature profile (13 pcs. 107-L by Campbell Scientific Inc., Logan, Utah, USA), air temperature (PT100, Vaisala, Helsinki, Finland), relative humidity (HMP155, Vaisala, Helsinki, Finland), soil frost (15 pcs. of SEC sensor by LISTEC, Isen, Germany) and soil dielectric constant, electric conductivity and temperature ( 9 pcs. of 5 TE by Decagon Devices, Pullman, Washington, USA) are made. More details about instrumentation (description, coordinates, sensor types and data availability) can be found from http://litdb.fmi.fi/ peatland.php. Manual snow pit measurements were made regularly (2-4 times per month) in 2009-2015. After 2015 SWE is measured manually only occasionally for calibration of automatic measurements.

\subsubsection{Sodankylä snow course}

The Sodankylä snow course (dots and circled dots in Fig. 1b and c) is a $4 \mathrm{~km}$ route in the vicinity of the FMI-ARC station crossing forested and open areas on mineral and organic soil. The Sodankylä snow course has 80 HS measurement locations, out of which 5 are in forest opening, 10 in pine dominated forest, 23 in spruce dominated forest, 5 in broadleafdominated forest and 37 in bog. The snow course has been measured regularly since 1959.

\subsubsection{Forest site}

The forest site is in a sparse pine forest on mineral sandy soil located in the FMI-ARC station area (o in Fig. 1b and c). Coniferous forest on mineral soil is the most common land cover type (32\%, Corine Land Cover 2006) in the Sodankylä area. The ground is covered with lichen (Cladonia rangiferina), lingonberry, cloudberry and moss as shown in Fig. 2c. The area has been fenced since 1958 allowing the lichen to grow undisturbed by reindeer. HS (from fixed stakes) and SWE have been measured every 5 days in January and March since 1972. There are automatic soil temperature (109-L by Campbell Scientific Inc., Logan, Utah, USA) and short- and longwave radiation (CNR4 by Kipp\&Zonen, Delft, The Netherlands) measurements at the site. Until 2014 there were automatic flux measurements of $\mathrm{CO}_{2}$ (LI840 from Li-Cor, Lincoln, Nebraska, USA) and $\mathrm{CH}_{4}$ (G1301 from
Picarro Inc., Santa Clara, California, USA). More details and data of the automatic measurements can be found at http://litdb.fmi.fi/lichen_fence.php.

\subsubsection{Intensive observation area}

The main present-day measurement site is the IOA (square in Fig. $1 \mathrm{~b}$ and $\mathrm{c}$ ). The IOA consists of a forest clearing (diameter about $40 \mathrm{~m}$ ) and the sparse pine forest around it as shown in Fig. $2 d$ (lower). Vegetation in the opening is mainly very low lichen $(<2 \mathrm{~cm})$ and some heather $(\sim 10 \mathrm{~cm})$ as shown in Fig. 2d (upper). Pine saplings are removed from the measurement area. The soil is composed of sand (70\%), silt $(29 \%)$ and clay $(1 \%)$ with a thin organic layer on top. The opening is shaded from most of the direct sunlight and protected from the wind by the forest surrounding it. As described in Sect. 2.1, mean wind speed on a similar forest opening at $1.5 \mathrm{~m}$ height is only $1.17 \mathrm{~m} \mathrm{~s}^{-1}$. Wind has a minimal effect on snow accumulation, and there is almost no snow redistribution by wind.

The measurement site was established in 2006 and today it hosts numerous automatic measurements: snow temperature profile (13 pcs. of 107-L by Campbell Scientific Inc., Logan, Utah, USA), HS (2 pcs. of SR50 by Campbell Scientific., Logan, Utah, USA), precipitation from distrometer (Thies Clima, Göttingen, Germany), brightness temperature with microwave radiometers $(1.4 \mathrm{GHz}$ from ELBARA-II by GAMMA Remote Sensing and Consulting AG, Gümligen, Switzerland (Schwank et al., 2010) and 10.6, 18.7, 21, 36.5, 89 and $150 \mathrm{GHz}$ from RPG-8CH-DP and RPG-4CH-DP radiometers by Radiometer Physics GmbH, Meckenheim, Germany), broadband albedo (CMA11 by Kipp \& Zonen, Delft, The Netherlands), spectral albedo (Field Spec pro JR by Analytical Spectral Devices, Boulder, Colorado, USA), SWE (SSG-1000 by Sommer Messtechnik, Koblach, Austria), air temperature (2 pcs. of PT100, Vaisala, Helsinki, Finland), air humidity (2 pcs. of HMP sensor, Vaisala, Helsinki, Finland), soil moisture and temperature ( 8 pcs. of Hydra Probe by Stevens Water Monitoring Systems, Portland, Oregon, USA), soil moisture (5 pcs. of ThetaProbe by Delta-T Devices, Cambridge, UK), soil temperature (2 pcs. of QMT103 by Vaisala, Helsinki, Finland) and soil dielectric constant, electric conductivity and temperature ( 9 pcs. of 5 TE by Decagon Devices, Pullman, Washington, USA). More details about instrumentation (description, coordinates, sensor types and data availability) can be found at http://litdb.fmi.fi/ioa.php. Snow pit measurements have been made regularly (2-4 times per month during the snow season) since 2006. The IOA snow course (HS from fixed stakes) has been measured together with the snow pit since 2009. Most of the automatic measurements, as well as the manual snow pits, are located in the forest clearing. In addition, several measurement campaigns have been performed at the IOA with variable instrumentation for snow measurements. 


\subsubsection{Lake Orajärvi}

Water courses and water bodies cover $3 \%$ the Sodankylä area (Corine Land Cover 2006). Lake Orajärvi is located $10 \mathrm{~km}$ east from FMI-ARC (Figs. 1b, 2e) and it is the closest lake to FMI-ARC. The measurement site on the lake is fixed, it is $400 \mathrm{~m}$ from the nearest shore and away from the snow mobile tracks crossing the lake.

Times of freezing and melting of the lake depend on air temperature; the lake usually freezes in December and melts in April, but the dates are not recorded. Freezing depends on the amount of snow fall during the process; if air cools before any heavy snowfall, the ice gets thick quickly, but heavy snowfall on thin ice slows down the ice formation. Typically water rises through cracks in the ice during the winter and refreezes over the solid ice. Snow is affected by strong sunlight in the springtime, strong (compared to e.g. the IOA) wind, the large temperature gradient between ice and air due to very shallow snowpack and water on ice. Snow on lake ice is quite heterogenic: wind-driven dunes, snow mobile tracks and water on ice are quite common. Thus, the representativeness of the snow stratigraphy measurements is problematic.

The site has no automatic measurements. Ice measurements (ice depth, ice layers and HS) have been made regularly (once or twice per month) from three fixed sites since 2008. Snow pit measurements were made regularly (once or twice per month) in 2008-2014.

\subsubsection{Sounding station}

The sounding station was built in 1949 when the FMI observatory was established, and it is the heart of meteorological observations in FMI-ARC ( $x$ in Fig. 1b and c). The area is mostly open with some sparse coniferous trees on mineral soil. Manual surface synoptic observations (SYNOP) observations, including daily snow depth, have been performed at the weather station next to the sounding station since 1949. Today there are numerous automatic measurements at the site, including an automatic weather station, solar radiation measurements and greenhouse gas column observations, which are described at http://litdb.fmi.fi/soundingst.php.

\subsubsection{Tanhua snow course}

Tanhua area is located $50 \mathrm{~km}$ northeast of FMI-ARC (Fig. 1a). The land cover is similar to FMI-ARC station with coniferous forests on mineral soil and open peat bogs. Tanhua snow course has 80 measurement locations, out of which 6 are in forest opening, 41 in pine dominated forest, 4 in spruce dominated forest and 29 in bog. In 2009-2014, FMI measured a $4 \mathrm{~km}$ long snow course in Tanhua monthly during a measurement campaign related to ESA CoReH20 satellite mission preparation. The area was chosen from the planned satellite flight track.

\subsection{Measurements and instruments}

This section defines the measurement protocols for each parameter and instruments used in each measurement. The measurement locations and years are listed for each parameter in Table 1 . The availability of each data set is listed in Table 3.

\subsubsection{Density and SWE}

\section{Bulk density and SWE}

Bulk SWE and density is measured with a Finnish type snow tube (originally Melander and Korhonen, 1923; more details in Finnish in SYKE, 2015). It is made of black plastic tubing, and is $70 \mathrm{~cm}$ high and $10 \mathrm{~cm}$ in diameter. There is a removable lid with a handle on one end of the tube, and the other end is re-enforced with a sharpened metal ring. Each tube is paired with a scale and the pair is calibrated to show SWE directly. A centimetre scale on the outside of the tube allows for the measurement of HS for density calculation.

The tube is first weighed empty to check the calibration (e.g. if several measurements are performed, some snow might be stuck in or on the tube and cause an offset). The tube is pushed vertically into snow until it hits the ground. Snow depth is recorded. Snow is removed from around the tube to allow a small flat shovel to be slid below the tube and used to seal the bottom when the snow sample is extracted. The tube is turned upside down, cleaned of any snow on the outside and vegetation inside, and weighed (Fig. 3b). The scale shows SWE directly. The offset is subtracted from the measured SWE. If there is more than $70 \mathrm{~cm}$ snow, several samples are taken on top of each other and weighed separately.

Vegetation and ground surface clearly affect the accuracy with which all the snow and only the snow (i.e. no vegetation or soil included) can be sampled. This can be minimised by the selection of the measurement site. The systematic error of the tube and scale is minimised by regular calibration measurements using standardised weights. In calibration measurement, the zero position of the scale can be tuned with a screw. The tube and scale are calibrated as a pair.

\section{Profile with samplers}

Density profile is measured similarly, but using a smaller sampler. Until 2014, the wedge-shaped RIP 2 cutter (Snowmetrics, Fort Collins, Colorado, USA) was used (Fig. 3c). Since 2015, a self-made box sampler (Fig. 3c) has been used. The self-made box sampler is a rectangular frame open at both ends. It has a handle on one end. Both samplers are $10 \mathrm{~cm} \times 10 \mathrm{~cm} \times 5 \mathrm{~cm}$ (total height of the box sampler, maximum height of the wedge sampler).

Density profile is measured in $5 \mathrm{~cm}$ steps beginning from the closest 5 or $10 \mathrm{~cm}$ below the snow surface. The bag or bucket used in snow weighting is first weighed empty. The 


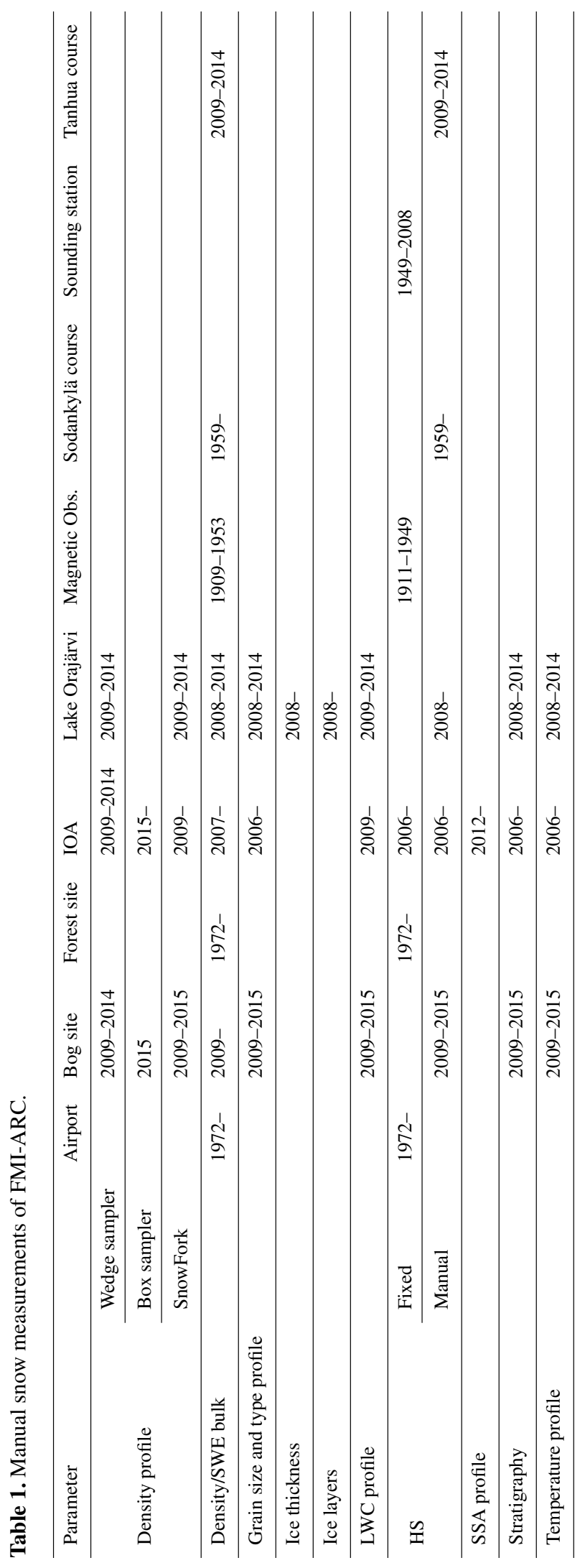

sampler is inserted into snow pit wall horizontally and perpendicular to the wall. The sampler is sealed; the RIP 2 cutter has a flat metal plate lid, while the box sampler has a rectangular frame that seals both ends. Snow sample is extracted and all snow is cleaned from the outside of the sampler. The snow sample put in a plastic bag or a small bucket, and weighed. Either mechanical or digital scale can be used. The mechanical spring balance (Pesola AG, Schindellegi, Switzerland) is more reliable in very cold conditions, while the digital one (OCS-1, Shenzhen West-Boao Science $\&$ Technology Co., Shenzhen, China) is easier to use. The whole snow profile is sampled and weighed in this manner.

Successive samples are not taken directly on top of each other, as snow might be disturbed from previous sampling, but the samples form a checkerboard pattern. Vegetation affects the measurement accuracy of samples from close to the ground. Problems with sampling occurs also in light new snow at top of the snowpack. Hard crust layers are difficult to penetrate with the sampler. On the other hand, keeping large coarse grains inside sampler is tricky. In those cases, occasionally successful sampling is not possible. With the RIP 2 cutter, snow escapes easily from the sampler especially if there are thin ice layers mixed with soft snow in the sampled layer. In addition, the pit wall has to be very smooth and the sampler needs to be inserted absolutely perpendicular to the wall to extract a good snow sample. These error sources are much smaller when the box sampler is used. Another possible error source is not weighting all the sampled snow (e.g. some of it stays in the sampler). This could be avoided by weighting the whole sampler with the snow, but in this case there is a bigger possibility of weighting additional snow that is, e.g., stuck on the sampler. One possible error source is having some snow from previous measurements already inside the sampler. These error sources are minimised by carefully cleaning the sampler and weighting bag or bucket between and during the measurements.

There is a difference between densities from the wedge and box samplers arising from the fact that snow is not homogeneous. Both of the samplers are $5 \mathrm{~cm}$ high, but when the box sampler gives an average density for the sampled snow, the wedge-shaped one gives a weighted average: most of the sampled snow is from the bottom of the sampled layer. In a homogeneous snow layer the difference is small, but as the vertical variation in the snowpack increases (i.e. the thinner and more varied the layers are), the difference between the samplers increases.

\section{Profile with SnowFork}

Measurement with the SnowFork is described in Sect. 2.3.4.

\subsubsection{Grain size and type}

Grain size $E$ of a layer is defined as "the average size of its grains", and the size of a grain is "its greatest extension mea- 
(a)

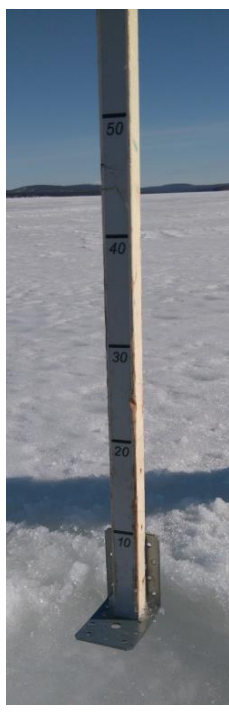

(b)

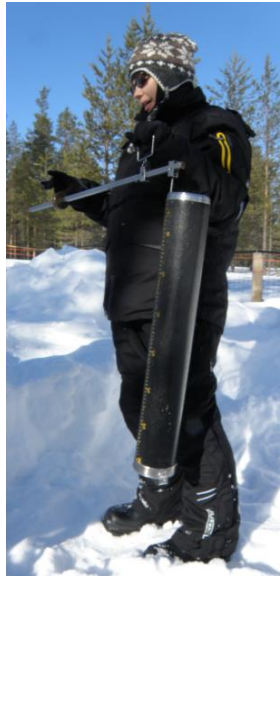

(f)

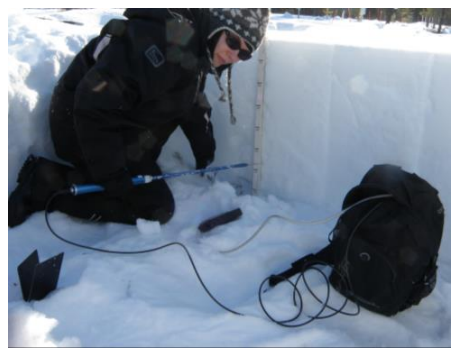

(i)

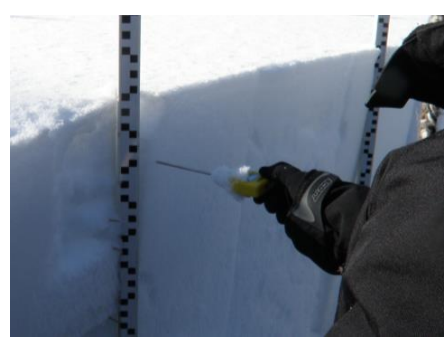

(c)

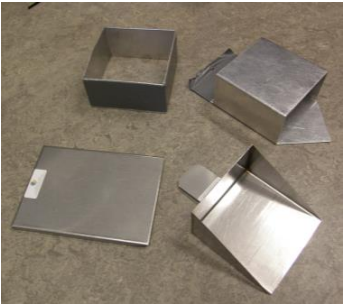

(e)

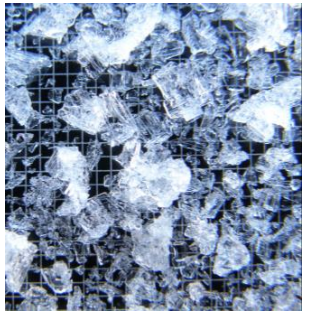

(g)

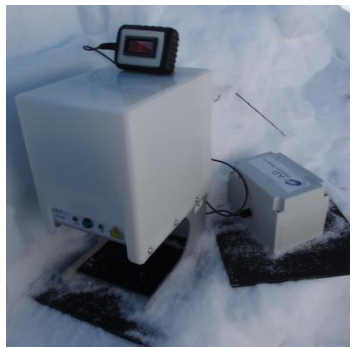

(j)

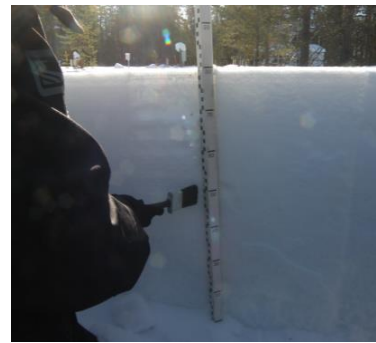

(d)
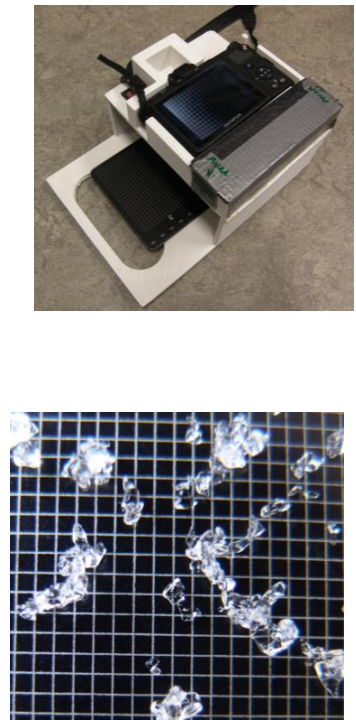

(h)

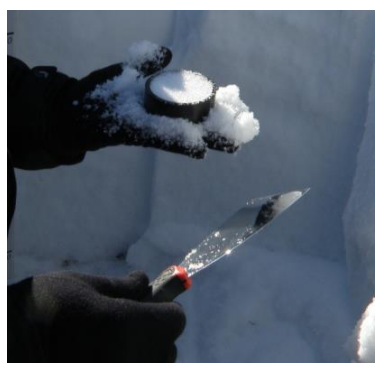

(k)

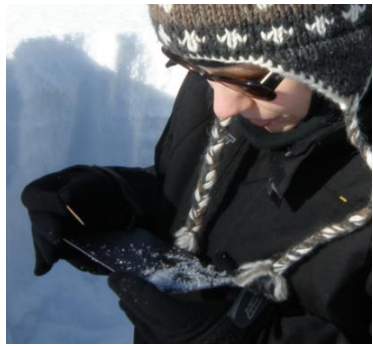

Figure 3. Photos of snow pit measurements: (a) tool for ice thickness measurements, (b) bulk SWE measurement with SWE tube, (c) box sampler and wedge sampler for density profile, (d) camera and stand for macro-photography, (e) two examples of snow grains on $1 \mathrm{~mm}$ grid, (f) SnowFork, (g) IceCube, (h) snow sample preparation for IceCube, (i) temperature measurement, (j) determining layers with brush and (k) definition of grain size and type in field.

sured in millimetres" in Fierz et al. (2009). Grain type describes shape and/or origin of a snow grain. Both parameters are defined for each layer in the field according to definitions by Fierz et al. (2009). In addition, macro-photographs of snow grains of each layer are taken against a $1 \mathrm{~mm}$ reference plate (by Sear) using a digital camera (resolution $3648 \times 2736$ and focal length $28 \mathrm{~mm}$ or resolution $3072 \times 2304$ and focal length $10 \mathrm{~mm}$ ) and self-made illuminated stand (Fig. 3d) from every layer in the snowpack. Layer detection is described in Sect. 2.3.7. Typical grains from each layer are photographed so that the grains are separated on the clean and ice free plate as well as possible without breaking them (Fig. 3e). Three photographs are taken from every layer to ensure success of photography and to have mildly differently orientated grains in all photographs. Photographs of different layers are separated by an empty photo. 
Post-processed grain size and type are estimated visually from the photographs on computer screen. Largest extent of an average grain and average largest grain (snow grain size $E$ and size of the largest grains $E_{\max }$, Fierz et al., 2009) are estimated with $0.25 \mathrm{~mm}$ resolution. It is possible to measure the size of a single grain with a much higher resolution, but practise has shown that error arising from multiple observers defining the average value for a layer is of this magnitude. Grain type estimation is based on classification by Fierz et al. (2009). Mostly used morphological grain classes are precipitation particles, decomposing and fragmented precipitation particles, surface hoar, rounded grains, faceted crystals, melt forms and depth hoar. The subclasses are listed by Fierz et al. (2009).

Main error sources are related to choosing and setting up the grains from snowpack to the plate and visual estimation of the snow grains. Estimation of grain size from the photographs is exposed to error from separating grains from clusters and positioning grains so that it is possible to estimate the largest extent. Visual estimation is also sensitive to observer-related bias. Advantages of post-processed grain size related to direct visual estimation of grain size and grain type in the field are the possibility of having a more accurate image than the with bare eye or magnifying lens, and the repeatability of the estimation. The measurement errors are described more closely by Leppänen et al. (2015).

\subsubsection{Ice thickness}

Ice thickness is measured with a wooden snow depth probe (Sect. 2.3.5), which has a small metal plate attached perpendicular to the probe at the $0 \mathrm{~cm}$ level (Fig. 3a). Thickness is measured by inserting the probe in a drill hole, attaching the metal plate below the ice, and reading the height of the ice surface level from the centimetre scale (Fig. 2e).

If the water surface level is higher than the ice surface, it is very difficult to read the ice thickness from the probe accurately. However, this situation is very rare. Another source of measurement errors is a bent metal plate, but this problem is easy to check and fix before performing the measurement.

\subsubsection{Liquid water content}

Liquid water content (LWC) describes the amount of liquid water in the snowpack, and can be derived, e.g., from the electrical conductivity of snow. The SnowFork instrument (Toikka Ltd., Engineering, Espoo, Finland) (Sihvola and Tiuri, 1986, Fig. 3f), measures the dielectricity of snow between two metal rods. The resonant frequency, attenuation and $3 \mathrm{~dB}$ bandwith are recorded, and inserted into equations by Sihvola and Tiuri (1986), which are used to derive density and LWC through real and imaginary parts of permittivity.

Measurement procedure includes calibration measurement in air and measurements from snowpack every $10 \mathrm{~cm}$. Snowpack is measured by pushing the metal rods of the Snow-
Fork horizontally and perpendicularly inside the smoothened snow pit wall to the desired height. Output values (attenuation, $3 \mathrm{~dB}$ bandwidth and resonant frequency) are recorded from the screen, and subsequently the instrument is ready for the next measurement. It is also possible to get density and LWC directly from the SnowFork, but the equations it uses are less accurate than the full equations by Sihvola and Tiuri (1986).

The equations used in deriving the density and LWC from the dielectric measurement assume that the surrounding material is homogeneous. There are two frequent cases, where this assumption is not valid: (1) at the surface and bottom of the snowpack close to air, ground or vegetation, and (2) if there is air around the rods (from the user moving the rods too much especially in very fluffy surface snow or large depth hoar crystals). Any metal objects (e.g. thermometer) close to the SnowFork cause errors, and must be removed before measurements. Another small error source is the fact that snow densifies when the rods are inserted. A comparison of the SnowFork and sampler densities (unpublished) showed that on average, the SnowFork gives $40 \mathrm{~kg} \mathrm{~m}^{-3}$ lower densities than the wedge sampler. In addition, the frequency measurement accuracy of the SnowFork is not enough to determine very low moisture contents (less than $\sim 1 \%$ ). An error in the measured height depends on the horizontal levelling of the SnowFork during the measurement.

\subsubsection{Snow depth}

HS can be measured either by a fixed stake or using a manual probe. In both cases, the instrument is the same wooden stake with $1 \mathrm{~cm}$ graduated scale (Figs. 2c, 3j). The cross section of the stake is $3 \mathrm{~cm} \times 3 \mathrm{~cm}$. A fixed stake is fastened in a vertical position with the $0 \mathrm{~cm}$ mark at ground surface to another smaller stake that is pushed into ground. Typical measurement errors are induced by a small pit or a pile of snow formed around the stake. This is minimised by removing the possible pile and estimating the true snow surface depth around the stake. Another error source is vegetation growing around the stake. However, lichen and moss grow very slowly and the error can be reduced by removing them from the stakes.

If the stake is used manually, the probe is pushed through the snow until it hits ground. Ground is recorded as $0 \mathrm{~cm}$ for HS. Measurement errors are caused by hard ice layers or vegetation that prevent the probe from hitting ground. These are minimised by repeating the measurement 3 times.

\subsubsection{Specific surface area}

Microstructural parameter specific surface area (SSA) is the ratio between surface area of ice and its mass in the snow sample (Legagneux et al., 2002). The IceCube instrument (A2 Photonic Sensors, Grenoble, France) (Fig. 3g, h) (Zuanon, 2013) is similar to DUFISSS presented by Gallet 
et al. (2009), but it uses only $1310 \mathrm{~nm}$ wavelength laser for reflectance measurements. Measurement procedure includes calibration, snow sampling, measurement of the snow samples with the instrument, and conversion of measured values to SSA with software. Calibration is made by measuring six differently shaded calibration standards; results are inserted afterwards to the software with measurement results.

Measurements are made from every $3 \mathrm{~cm}$ from whole snowpack. Snow is collected from certain height of the snowpack to $2.45 \mathrm{~cm}$ high and $6 \mathrm{~cm}$ diameter sample holder with a spatula or a sampling tool provided with the instrument. Very light snow (e.g. fresh snow) needs compaction to avoid reflection from the bottom of the sampler holder instead of the snow. The surface of the sample is smoothed and broken grains are removed with a spatula to avoid additional scattering of the laser. Sampling of very coarse grained snow or ice layers is difficult, because the sample surface should be even and smooth. The outside of the sample holder has to be clean of snow. The measurement is made by inserting the prepared snow sample into the instrument under the laser, and reading the corresponding voltage from a screen. Afterwards a software provided by the instrument manufacturer is used to convert the measured values to SSA. A logger, which records and shows SSA values directly in the field, is also available from the manufacturer, but it is not in use at FMI-ARC.

Measurement errors originate mainly from the sample preparation (e.g. packing of the snow to sample holder, smoothing of the sample surface, and height of the sample). The orientation of snow grains in the sample affects the observed reflectance; therefore, slightly different results can be measured by rotating the sample during measurement. Successful calibration measurements are also needed for accurate results. A further discussion of error sources is presented by Leppänen et al. (2015).

\subsubsection{Stratigraphy}

Horizontal layers of the snowpack are defined from smoothened snowpack wall from visual appearance and differences of hardness, wetness, grain size and grain type with the help of a paintbrush (for removing very soft layers, Fig. 3j) and tooth picks (for detecting thin hard layers). Grain size and type, hardness and wetness are estimated with a hand scale for every layer as described by Fierz et al. (2009). Grain size and type are estimated visually against the same $1 \mathrm{~mm}$ reference grid, which is used for macrophotography (Sect. 2.3.2 and Fig. 3k). Upper heights of the layers are recorded with accuracy of $5 \mathrm{~mm}$ and marked with toothpicks. Completed layer profile in snowpack is photographed.

Most of the errors related to the stratigraphy originate from inhomogeneities of the snowpack. Layer interfaces are not always clear, instead the snow structure might change gradually. Occasionally, layers are not continuous or a layer includes inhomogeneous spots inside it, which cannot be recorded as separate layer. Errors are also related to the used accuracy, very thin layers might not be recorded separately. There are also observer-related biases in layer definition and estimation of layer properties with hand scale. Especially, hardness is related to power, which is used for pushing hand, four fingers, one finger, pen or blade to the snowpack. Grain size estimation also depends on the observer. Therefore, stratigraphy is defined by one person for a snow pit. The discussion of error sources is presented by Leppänen et al. (2015).

\subsubsection{Temperature}

Temperature is measured with TH310 thermometers (Milwaukee Electronics Kft., Szeged, Hungary). The thermometer is first cooled in air and air temperature is recorded. The $\sim 10 \mathrm{~cm}$ long probe of the thermometer is inserted completely horizontally and perpendicularly into snowpack and left to reach thermal equalisation for a few minutes until the reading does not change anymore (Fig. 3i). Measurements are made every $10 \mathrm{~cm}$ from snowpack starting from snow surface towards ground, also ground surface temperature is recorded. Snow surface temperature is measured by inserting the thermometer probe under the uppermost $\sim 5 \mathrm{~mm}$ of snow.

One error source is the height and angle at which the thermometer is inserted into the snowpack. Surface temperature has an error related to amount of covering snow. When the Sun's elevation is high enough, solar radiation may have an effect on the temperature in the uppermost measurements. Ground surface temperature has an error related to the position of the thermometer tip, as measurements inside vegetation (lichen and moss) or soil are different from snow. Thermometer needs to be calibrated for correct results.

\section{Data sets}

This section describes the data sets and lists their measurements and sites.

\subsection{Snow pit}

Snow pits have been measured at the IOA, the bog site and Lake Orajärvi (Sect. 2.2.5, 2.2.2 and 2.2.6, and Fig. 2). The observation years with different instruments and measurement sites are presented in Table 1. Main problems in measurements are the duration of day light in mid-winter during the polar night, very cold air temperature in mid-winter and positive air temperature in spring. Measurements are made usually in the morning (while it is still cold) or midday (to have enough light). Air temperature limit for measurements is $-25^{\circ} \mathrm{C}$; if the weather is colder, measurements are shifted to another day. The bog site and Lake Orajärvi become impassable in the melting period, and therefore those measurements are usually finished before the measurements at the IOA. 


\subsubsection{Procedure}

At the beginning of the measurement day, instruments that need thermal stabilisation are moved outside for cooling. All equipment is gathered on a sledge and transferred to the measurement site where they are kept in the shade to avoid warming. Snow pit measurements are made by $2-3$ observers at a time. Snow pit observations are made on same fixed areas to allow for the comparison of measurements between years. Snowpack is disturbed as little as possible, and passage to the measurement areas is limited to one track. A new snow pit is dug at least $\sim 50 \mathrm{~cm}$ away from the old ones to avoid changes in the snow structure due to previous pit measurements. This introduces spatial heterogeneity in the measurements, but is unavoidable due to the destructive nature of the measurements. Spatial variability is unaccounted, but the snow pit sites were chosen to be flat without large vegetation or topography variations. The removed snow is placed on already used areas, and the snow surface is levelled after the measurements.

The examined snow pit wall is in the shade to avoid temperature changes and melting caused by solar radiation. The wall is smoothened with a shovel or a metal plate. Measurements are commenced immediately after digging the pit to avoid additional metamorphism. A snow pit measurement includes photography of the surroundings (landscape, sky, snow pit area, ground), temperature profile $(10 \mathrm{~cm}$ interval) simultaneously with the definition of horizontal layers and stratigraphy, density and LWC profile $(10 \mathrm{~cm}$ interval) with the SnowFork, density profile ( $5 \mathrm{~cm}$ interval) with a sampler, bulk SWE, SSA profile ( $3 \mathrm{~cm}$ interval) and HS in presented order. The number of measurements included in the snow pit has increased; in 2006 only HS, temperature profile, grain sizes and stratigraphy were recorded. In 2015 a new protocol defining the order and placement of the different measurements in the pit was defined (Fig. 4). This insures that grain size and SSA measurements are made next to each other, as well as SWE and density measurements. At the end of the measurements, a photograph of the filled notebook is taken. Afterwards all equipment are dried, batteries are reloaded and data is digitised and stored.

Detailed description of the parameters, used instrumentation and measurements are in Sect. 2.3. Photographs of measurements and equipment are presented in Fig. 3. For all measurements, $0 \mathrm{~cm}$ HS is the ground.

\subsubsection{Example data}

There is a large amount of data from snow pit measurements from the last 10 winters. Therefore, only some examples of the data set are presented here. Density measurements and temperatures from different snow heights are presented in Fig. 5 from the IOA in 2013-2014. Density measurements with the SnowFork are usually smaller than measurements with the sampler or SWE tube. The average from density

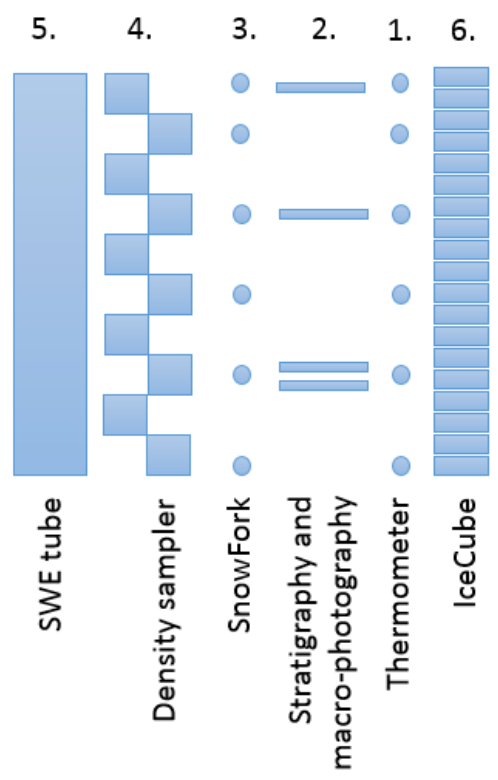

Figure 4. Snow pit measurements have been made with this plan since 2015. Measurements are made in numbered order.

sampler does not necessarily include the whole snowpack, as the surface layer of $<5 \mathrm{~cm}$ thickness is not measured, and some snow types are very difficult to sample with the cutter (e.g. hard crust layers, fragile depth hoar, soft fresh snow or slush). This explains some of the differences between the SWE tube and density sampler. In a typical temperature profile, the warmest snow is at the bottom $(0 \mathrm{~cm})$. However, the temperature of the snow surface is highly dependent on air temperature. Typically the coldest point is close to the surface ( 30 or $50 \mathrm{~cm}$ depending on HS).

HS and SWE from the three pit sites in 2006-2015 are presented in Fig. 6a and b, respectively, and compared to the snow course measurements. HS and SWE are largest at the IOA and smallest at Lake Orajärvi. Maximum yearly HS varied $65-106 \mathrm{~cm}$ at the IOA, $54-80 \mathrm{~cm}$ at the bog site and $23-$ $44 \mathrm{~cm}$ at Lake Orajärvi. The HS and SWE at the bog site typically fall between the error bars of standard deviation of the measurements at the snow course, while the IOA has more snow and Lake Orajärvi has less snow than the snow course.

\subsection{Snow courses}

\subsubsection{Long snow courses}

Finnish Environment Institute (SYKE) maintains a network of 140 snow courses in Finland. Snow course measurements of SYKE and FMI began in the 1930s. Usually, there are 80 HS measurements made at regular intervals $(50 \mathrm{~m})$ along a $4 \mathrm{~km}$ course, and, in addition, 8 of these locations are chosen for SWE measurements so that each land cover type has at least one SWE measurement, and the most common have several measurements. The locations of the courses are se- 
(a)

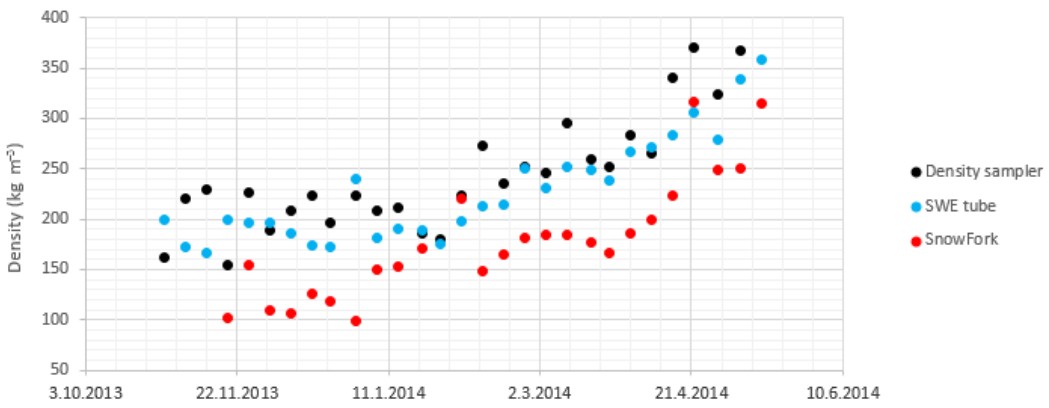

(b)

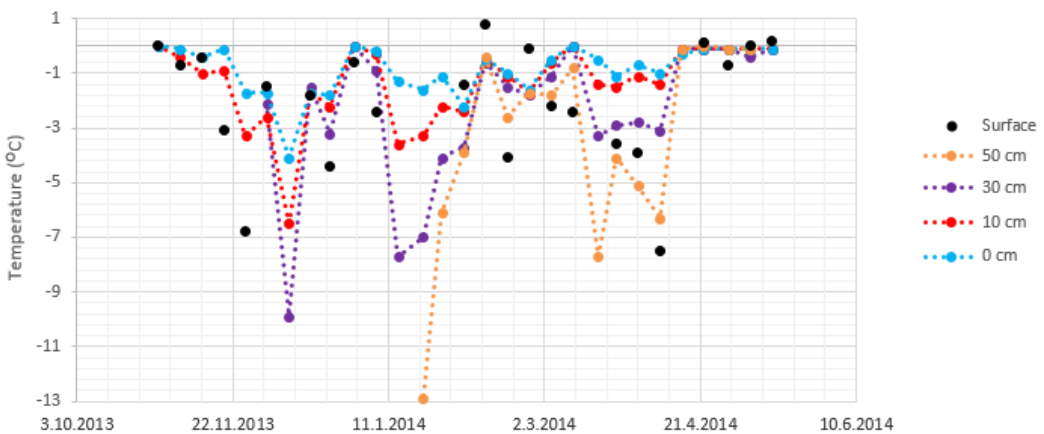

Figure 5. Example data from 2013 to 2014 snow pits at the IOA. (a) Densities from different instruments (average of density sampler profile, average of the SnowFork profile, and SWE tube). (b) Temperatures from different depths.

(a)

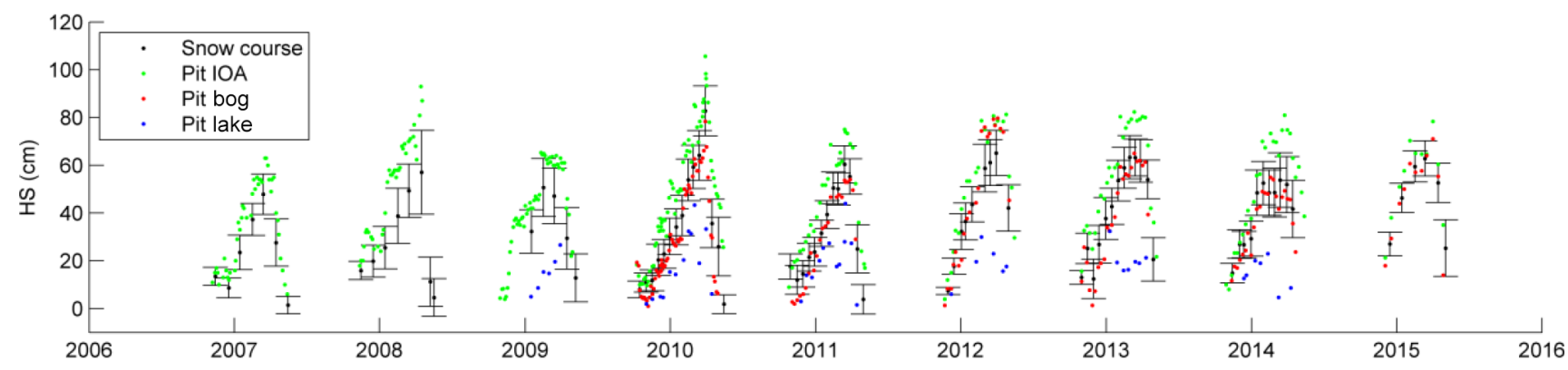

(b)

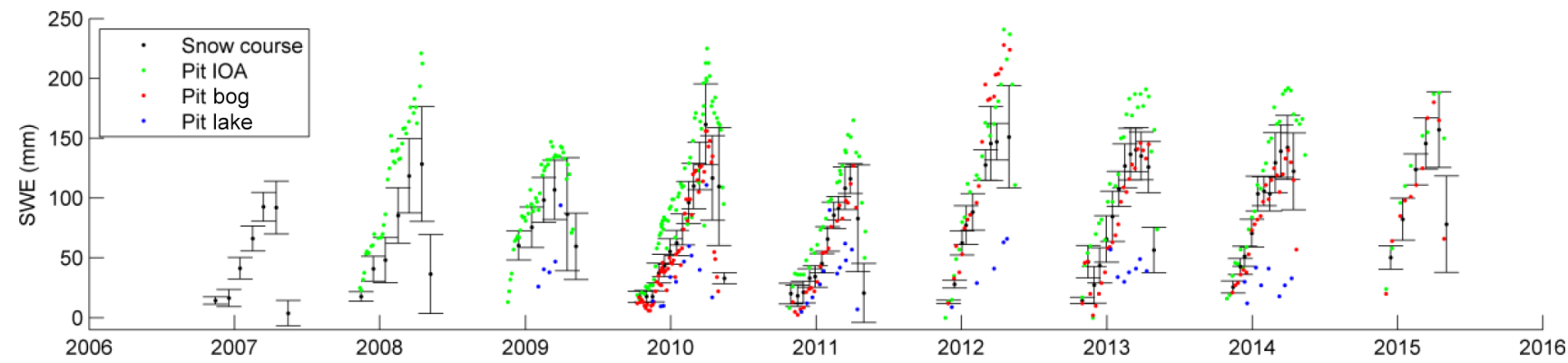

Figure 6. Time series of (a) HS and (b) SWE measurements from 2006 to 2016 from the Sodankylä snow course and from the three snow pit sites. Mean values of all measurements from the snow course with error bars of standard deviation are shown. For snow pits, the mean of three measurements is shown. 
lected for good coverage of the terrain, vegetation and land covers typical to the area. The main use for the snow course data is river runoff forecasting, and therefore the courses are located in the major watersheds. The measurement locations are classified into six categories: open area, forest opening, pine-dominated forest, spruce-dominated forest, broadleafdominated forest, and open bog. The classification of each location is made on the field when the course is established (or when there are major changes in land cover, e.g. a forest is cleared). The snow course measurements represent the variation in general snow conditions on the area and in each category.

One snow course has been located around FMI-ARC station in Sodankylä (Sect. 2.2.3) and measured by FMI personnel since 1959. The snow course is measured in the middle of each month; before 1991 only in January and March, and beginning in 1991 every month during the snow season. In 1991-1996 the course was additionally measured at the turn of the month. Moreover, in 2009-2014 FMI-ARC measured the Sodankylä snow course and an additional course in Tanhua (50 km northeast of Sodankylä, Sect. 2.2.8) at the turn of the month during a measurement campaign.

Both the Sodankylä snow course and the Tanhua snow course include $80 \mathrm{HS}$ and $8 \mathrm{SWE}$ measurements at fixed sites with regular intervals along a $4 \mathrm{~km}$ course. The course is measured using a snowmobile, skis or snowshoes, and measurements are made as described in Sect. 2.3.1 and 2.3.5 from the sites marked in GPS and in the field.

\subsubsection{Short IOA snow course}

A short HS course with fixed stakes is located at the IOA. The snow course consists eight stakes in open area and nine stakes in forest. The snow course has been measured together with the IOA snow pit (2-4 times per month) since 2009 at open area and since 2011 at forest. The reading of a fixed stake is described in Sect. 2.3.5.

\subsubsection{Example data}

The averages and standard deviations of HS and SWE measurements of the Sodankylä snow course in 2006-2016 are shown in Fig. 6 together with the snow pit measurements. The measurements are analysed in Sect. 3.1.2.

\subsection{Lake ice observations}

Lake ice observations are made in Lake Orajärvi (Sect. 2.2.6) and measurements include ice thickness, ice layers and HS on ice. The measurements were began in 2008, and in 20082014 an additional snow pit was measured at the first drill site. However, due to the high variability of snow depth and stratification on lake ice, the snow pit measurements were finished because of issues with representativeness. A photograph from the ice thickness measurements on Lake Orajärvi is shown in Fig. 2e. Lake ice observations are only made when the ice is thick enough to allow for safe passage. Thus, the first ice in the autumn and the melting ice in the spring are not measured.

\subsubsection{Procedure}

Ice thickness and HS are monitored around three permanent spots $20 \mathrm{~m}$ apart. Each time, a new drill site with untouched snow is chosen close to the marked spot. Three HS measurements are made at each spot with a manual probe around the drill site (see Sect. 2.3.5). Then snow is removed from the drill site. A hole is drilled almost through the ice. The thicknesses of layers of hard ice and softer snow-ice (frozen slush and snow), as well as possible water layers inside the ice, are detected by testing the hardness of the layers with the metal plate of the ice thickness probe and by visual inspection. The hole is drilled completely through the ice, and ice thickness is measured, as described in Sect. 2.3.3. Also the level of water surface from the bottom of the ice is recorded.

\subsubsection{Example data}

Ice thickness and HS on ice observations are summarised in Table 2. Maximum measured ice thickness varied between 60 and $76 \mathrm{~cm}$, while maximum measured HS varied between 19 and $43 \mathrm{~cm}$.

\subsection{Daily HS time series}

A daily time series of HS in Sodankylä has existed since 1 January 1911, with the exception of the year 1913 (move to the research station area), autumn 1941 (World War II) and autumn 1944 (World War II), which are missing. These data have been collected from several measurement sites: in 1911-1912 all the meteorological measurements were made in the town of Sodankylä. Since 1913, the establishment of the Magnetic Observatory, the measurements have been made at the current research station area, but the exact location of HS measurements before 1949 is unknown. Since 1949 HS has been measured at the Sounding station (Sect. 2.2.7 and Fig. 1). However, the coordinates of the measurement site in the meteorological yearbook did not change in 1949, so the previous location was not far away from the current site. Despite the changes in measurement location, the data set represents the best knowledge of snow depth conditions in Sodankylä. The earliest measurements have been digitised from meteorological yearbooks.

Last manual synoptic observations were made in December 2008, and afterwards there are only automatic HS measurements available (SR50 by Campbell Scientific Inc., Logan, Utah, USA) from the Sounding station. The HS time series, as well as some other automatic and manual measurements, is available at http://litdb.fmi.fi/luo0016_data.php. 
Table 2. Summary of the lake ice observations.

\begin{tabular}{lccccc}
\hline Year & \multicolumn{2}{c}{ Ice thickness in } & & \multicolumn{2}{c}{ Maximum measured } \\
\cline { 2 - 3 } \cline { 5 - 6 } & $\begin{array}{c}\text { mid-January } \\
(\mathrm{cm})\end{array}$ & $\begin{array}{c}\text { mid-March } \\
(\mathrm{cm})\end{array}$ & & $\begin{array}{c}\text { ice thickness } \\
(\mathrm{cm})\end{array}$ & $\begin{array}{c}\text { snow depth } \\
(\mathrm{cm})\end{array}$ \\
\hline $2008-2009$ & 39 & 64 & & 70 & 19 \\
$2009-2010$ & 45 & 67 & & 68 & 43 \\
$2010-2011$ & 50 & 67 & & 70 & 29 \\
$2011-2012$ & 26 & 53 & & 60 & 28 \\
$2012-2013$ & 34 & 62 & & 70 & 32 \\
$2013-2014$ & 37 & 60 & & 60 & 23 \\
$2014-2015$ & 51 & 76 & & 76 & 30 \\
\hline
\end{tabular}

Table 3. Availability of the data during the time of the paper's preparation. Different properties of data sets are marked under the data set column. The updated version of this table with direct links to the data sets can be found in http://litdb.fmi.fi/manual_measurements.php.

\begin{tabular}{llll}
\hline Data set & & Electronically available & Availability \\
\hline Snow pit & $2006-$ & On request \\
\hline IOA snow course & $2009-$ & On request \\
\hline \multirow{2}{*}{ Sodankylä snow course } & Middle of month & $1991-$ & $\begin{array}{l}\text { http://www.syke.fi/openinformation (averages), } \\
\text { on request (full data set) }\end{array}$ \\
\cline { 2 - 4 } & Beginning of month & $2009-2014$ & On request \\
\hline Tanhua snow course & & $2009-2014$ & On request \\
\hline Lake ice observations & & $2009-$ & On request \\
\hline \multirow{2}{*}{ Daily HS } & Magnetic Observatory & $1911-1949$ & http://litdb.fmi.fi/luo0016_data.php \\
\cline { 2 - 4 } & Sounding station & $1949-2008$ & On request \\
\hline \multirow{2}{*}{ SWE and HS } & Magnetic Observatory & $1914-1917,1920-1927,1941$, & On request \\
\cline { 2 - 4 } & Airport and forest & $1972-$ &
\end{tabular}

\subsubsection{Procedure}

Snow depth is read from a fixed HS stake as described in Sect. 2.3.5. Until May 1960, one value per day at 06:00 UTC was recorded. From June 1960 to December 2008, two values at 06:00 and 18:00 were recorded, but the 06:00 value is the daily snow depth. From February 2008, an automatic acoustic measurement (SR50 from Campbell Scientific Inc., Logan, Utah, USA) is recorded every $10 \mathrm{~min}$ ( $10 \mathrm{~min}$ average), with the 06:00 measurement still recorded as the daily snow depth.

\subsubsection{Example data}

The daily HS time series is shown in Fig. 7 together with the HS measurements from the airport and the forest site. Continuous snow has fallen the earliest on day 261 (year 1998) and latest on day 348 (year 2000). The last day of snow on the ground in spring has varied from day 114 (year 1937) to day 166 (year 1911). The absolute maximum HS in this data set is $119 \mathrm{~cm}$ (on 6 April 2000).

\subsection{SWE and HS time series}

There are two long time series of snow density, depth and SWE measured in Sodankylä: (1) between years 1909 and 1953 at a single measurement site and (2) an ongoing data set starting in 1972 at two sites. Until 2002, measurements were performed on the morning of 5th, 10th, 15th, 20th, 25th and the last day of every month, if there was snow on the ground. From 2002 onwards there are measurements only in January and March. The data set from 1909 to 1953 was measured by the Magnetic Observatory and the exact measurement site is unknown. Measurements from years 1914-1917, 1920-1927, 1941, 1945, 1948 and 1951-1953 are available in digitised form. The second data set from 1972 onwards is measured by FMI from two measurement sites: the airport (an open area, Sect. 2.2.1 and Fig. 2c), and the forest site 
(a)

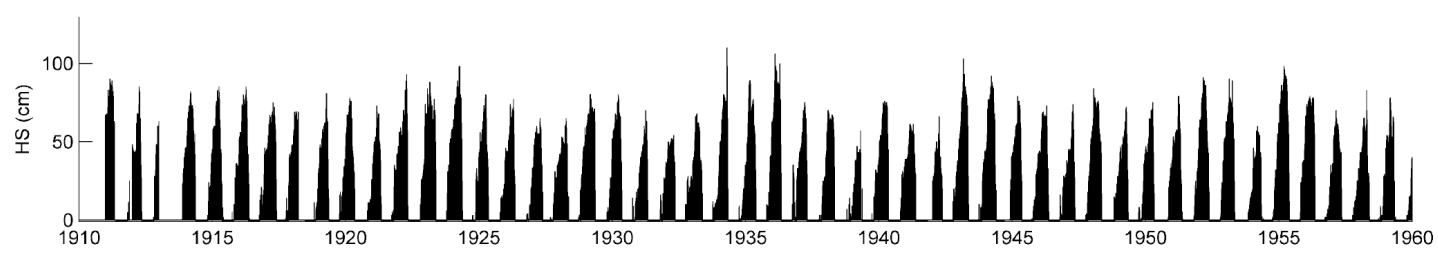

(b)

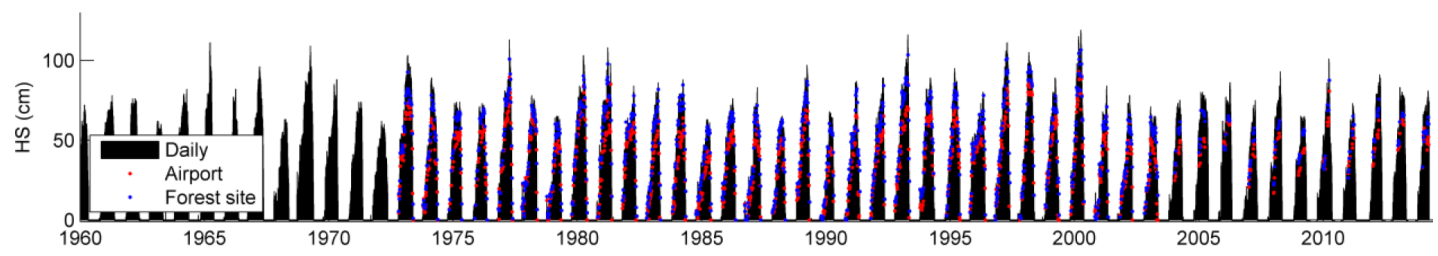

(c)

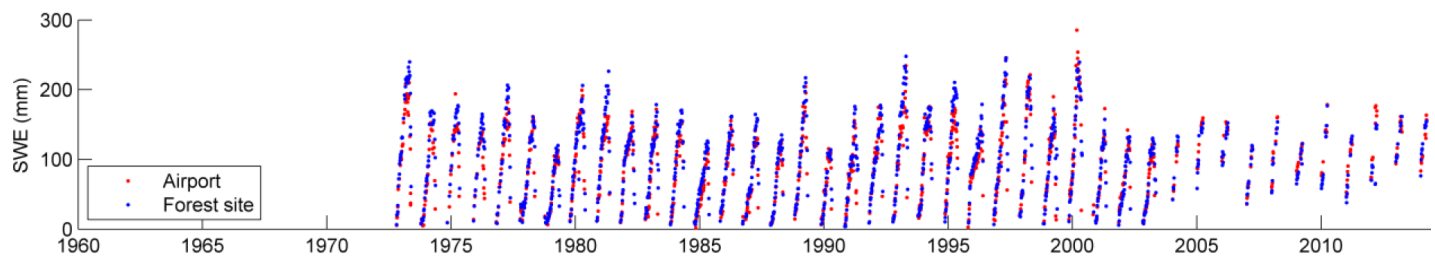

Figure 7. Time series in (a) and (b) HS measurements in 1911-2015, and (c) SWE measurements every 5 days (only in January and March from 2002) in 1972-2015.

(Sect. 2.2.4 and Fig. 2d). All SWE and HS measurements from 1972 onwards have been digitised.

\subsubsection{Procedure}

Two SWE samples are taken at each site. Until January 1924, SWE was measured by coring a cylindrical sample of snow with a tube of $100 \mathrm{~cm}^{2}$ cross sectional area, melting the snow in a covered bucket and measuring the volume of meltwater. From 1924, a special scale calibrated to show SWE (see Sect. 2.3.1) has been used to weight the cored snow sample (Fig. 4e). HS from a centimetre scale on the outside of the sampling tube is recorded; snow density can be calculated from HS and SWE.

Since 1976, HS at five fixed stakes (see Sect. 2.3.5) has been recorded at both sites. In 1972-1976, there were 9 stakes and two SWE measurements at the airport, and 25 stakes and four SWE measurements at the forest site.

\subsubsection{Example data}

The HS and SWE from the airport and the forest site are shown in Fig. 7. The HS at the forest site is comparable to the daily snow depth measurements, while the HS at the airport is typically lower; the mean difference between measurements at the forest site and the airport is $8.6 \mathrm{~cm}$. However, SWE at the two sites is about the same, the forest site has on average a $5.9 \mathrm{~mm}$ larger value. This means that snow at the airport is denser than at the forest site.

\section{Summary}

The Sodankylä manual snow survey program includes manual measurements of natural seasonal snowpack in the northern Finland. Measurements are performed at several diverse measurement sites at FMI-ARC. The station is equipped with a comprehensive set of tools for the manual measurements of snow and extensive reference instrumentation for automatic snow measurements and meteorological measurements. Measurements of HS and SWE have been made since 1909 (available since 1911 and 1914, respectively), and exact observations of snow macro- and microstructure have been made and available since 2006 from the snow pits. This paper presents a summary of the collected data sets.

\section{Data availability}

The availability of the data is described in Table 3 . The details on how to download the data can be found in http:// litdb.fmi.fi/manual_measurements.php. The digitising of the 
earliest measurements is ongoing and details will be updated to http://litdb.fmi.fi/manual_measurements.php. The averages of the SYKE snow course data are available from SYKE database (http://www.syke.fi/openinformation), and full measurement data from SYKE on request (details in http://litdb.fmi.fi/manual_measurements.php).

Acknowledgements. We thank the personnel of FMI-ARC, who participated in the manual snow measurements. Anita Sassali and Hanne Suokanerva are acknowledged for digitizing the HS and SWE time series. Pirkko Kaukonen from SGO and the staff of FMI library in Helsinki provided information of the earliest measurements. The manuscript preparation was supported by the EU 7th Framework Program project "European-Russian Centre for cooperation in the Arctic and Sub-Arctic environmental and climate research" (EuRuCAS, grant 295068).

Edited by: C. Ménard

\section{References}

Barnett, T. P., Adam, J. C., and Lettenmaier, D. P.: Potential Impacts of a Warming Climate on Water Availability in Snow-Dominated Regions, Nature, 438, 303-309, 2005.

Cheng, B., Vihma, T., Rontu, L., Kontu, A., Pour, H. K., Duguay, C., and Pulliainen, J.: Evolution of snow and ice temperature, thickness and energy balance in Lake Orajarvi, northern Finland, Tellus A, 66, 21564, doi:10.3402/tellusa.v66.21564, 2014.

Cohen, J. and Rind, D.: The effect of snow cover on the climate, J. Climate, 4, 689-706, 1991.

Colbeck, S. C.: An overview of seasonal snow metamorphism, Rev. Geophys. Space Phys., 20, 45-61, 1982.

Colbeck, S. C.: The layered character of snow covers, Rev. Geophys., 29, 81-96, 1991.

Derksen, C., Sturm, M., Liston, G. E., Holmgren, J., Huntington, H., Silis, A., and Solie, D.: Northwest territories and Nunavut snow characteristics from a subarctic traverse: Implications for passive microwave remote sensing, J. Hydrometeorol., 10, 448463, 2009.

de Rosnay, P., Balsamo, G., Albergel, C., Muñoz-Sabater, J., and Isaksen, L.: Initialisation of land surface variables for numerical weather prediction, Surv. Geophys., 35, 607-621, 2014.

Essery, R., Kontu, A., Lemmetyinen, J., Dumon, M., and Ménard, C. B.: A 7-year dataset for driving and evaluating snow models at an arctic site (Sodankylä, Finland), Geosci. Instrum. Method. Data Syst. Discuss., doi:10.5194/gi-2015-35, in review, 2016.

FMI-ARC database: http://litdb.fmi.fi/manual_measurements.php, last access: 11 May 2016.

Fierz, C., Armstrong, R. L., Durand, Y., Etchevers, P., Greene, E., McClung, D. M., Nishimura, K., Satyawali, P. K., and Sokratov, S. A.: The International Classification for Seasonal Snow on the Ground, IHP-VII Technical Documents in Hydrology $\mathrm{N}^{\circ} 83$, IACS Contribution $\mathrm{N}^{\circ}$ 1, UNESCO-IHP, Paris, 2009.

Gallet, J.-C., Domine, F., Zender, C. S., and Picard, G.: Measurement of the specific surface area of snow using infrared reflectance in an integrating sphere at 1310 and $1550 \mathrm{~nm}$, The Cryosphere, 3, 167-182, doi:10.5194/tc-3-167-2009, 2009.
Groisman, P. Y., Karl, T. R., Knight, R. W., and Stenchikov, G. L.: Changes of snow cover, temperature, and radiative heat balance over the Northern Hemisphere, J. Climate, 7, 1633-1656, 1994.

Hall, A. and Qu, X.: Using the current seasonal cycle to constrain snow albedo feedback in future climate change, Geophys. Res. Lett., 33, L03502, doi:10.1029/2005GL025127, 2006.

Hannula, H.-R., Lemmetyinen, J., Kontu, A., Derksen, C., and Pulliainen, J.: Spatial and Temporal Variation of Bulk Snow Properties in North Boreal and Tundra Environments Based on Extensive Field Measurements, Geosci. Instrum. Method. Data Syst. Discuss., doi:10.5194/gi-2015-37, in review, 2016.

Hardy, J. P., Groffman, P. M., Fitzhugh, R. D., Henry, K. S., Welman, A. T., Demers, J. D., Fahey, T. J., Driscoll, C. T., Tierney, G. L., and Nolan, S.: Snow depth manipulation and its influence on soil frost and water dynamics in a northern hardwood forest, Biogeochemistry, 56, 151-174, 2001.

Hernández-Henríquez, M. A., Déry, S. J., and Derksen, C.: Polar amplification and elevation-dependence in trends of Northern Hemisphere snow cover extent, 1971-2014, Environ. Res. Lett., 10, 044010, doi:10.1088/1748-9326/10/4/044010, 2015.

Ikonen, J., Vehviläinen, J., Rautiainen, K., Smolander, T., Lemmetyinen, J., Bircher, S., and Pulliainen, J.: The Sodankylä insitu soil moisture observation network: an example application to Earth Observation data product evaluation, Geosci. Instrum. Method. Data Syst. Discuss., 5, 599-629, doi:10.5194/gid-5599-2015, 2015.

Kangas, M., Rontu, L., Fortelius, C., Aurela, M., and Poikonen, A.: Weather model verification using Sodankylä mast measurements, Geosci. Instrum. Method. Data Syst., 5, 75-84, doi:10.5194/gi5-75-2016, 2016.

Kontu, A. and Pulliainen, J.: Simulation of spaceborne microwave radiometer measuremetns of snow cover using in situ data and brightness temperature modeling, IEEE T. Geosci. Remote, 48, 1031-1044, 2010.

Kontu, A., Lemmetyinen, J., Pullainen, J., Seppänen, J., and Hallikainen, M.: Observation and modeling of the microwave brightness temperature of snow covered frozen lakes and wetlands, IEEE T. Geosci. Remote, 52, 3275-3288, 2014.

Lakkala, K., Suokanerva, H., Karhu, J. M., Aarva, A., Poikonen, A., Karppinen, T., Ahponen, M., Hannula, H.-R., Kontu, A., and Kyrö, E.: Optical laboratory facilities at the Finnish Meteorological Institute - Arctic Research Centre, Geosci. Instrum. Method. Data Syst. Discuss., doi:10.5194/gi-2015-43, in review, 2016.

Legagneux, L., Cabanes, A., and Dominé, F.: Measurement of the specific surface area of 176 snow samples using methane adsorption at $77 \mathrm{~K}$, J. Geophys. Res., 107, 4335, doi:10.1029/2001JD001016, 2002.

Leinss, S., Wiesmann, A., Lemmetyinen, J., and Hajnsek, I.: Snow water equivalent of dry snow measured by differential interferometry, IEEE J. Sel. Top. Appl., 8, 3773-3790, 2015.

Lemmetyinen, J., Derksen, C., Toose, P., Proksch, M., Pulliainen, J., Kontu, A., Rautiainen, K., Seppänen, J., and Hallikainen, M.: Simulating seasonally and spatially varying snow cover brightness temperature using HUT snow emission model and retrieval of a microwave effective grain size, Remote Sens. Environ., 156, 71-95, 2015.

Lemmetyinen, J., Schwank, M., Rautiainen, K., Kontu, A., Parkkinen, T., Mätzler, C., Wiesmann, A., Wegmüller, U., Derksen, C., Toose, P., Roy, A., and Pulliainen, J.: Snow den- 
sity and ground permittivity retrieved from L-band radiometry: Application to experimental data, Remote Sens. Environ., doi:10.1016/j.rse.2016.02.002, online first, 2016a.

Lemmetyinen, J., Kontu, A., Pulliainen, J., Vehviläinen, J., Rautiainen, K., Wiesmann, A., Mätzler, C., Werner, C., Rott, H., Nagler, T., Schneebeli, M., Proksch, M., Schüttemeyer, D., Kern, M., and Davidson, M.: Nordic Snow Radar Experiment, Geosci. Instrum. Method. Data Syst. Discuss., doi:10.5194/gi-2015-29, in review, 2016b.

Leppänen, L., Kontu, A., Vehviläinen, J., Lemmetyinen, J., and Pulliainen, J.: Comparison of traditional and optical grain-size field measurements with SNOWPACK simulations in a taiga snowpack, J. Glaciol., 61, 151-162, 2015.

Mäkelä, J. S., Lakkala, K., Koskela, T., Karppinen, T., Karhu, J. M., Savastiouk, V., Suokanerva, H., Kaurola, J., Arola, A., Lindfors, A. V., Meinander, O., Leeuw, G., and Heikkilä, A.: Data flow of spectral UV measurements at Sodankylä and Jokioinen, Geosci. Instrum. Method. Data Syst. Discuss., doi:10.5194/gi-2015-42, in review, 2016.

Marty, C. and Meister, R.: Long-term snow and weather observations at Weissfluhjoch and its relation to other high-altitude observatories in the Alps, Theor. Appl. Climatol., 110, 573-583, 2012.

Meinander, O., Kontu, A., Lakkala, K., Heikkilä, A., Ylianttila, L., and Toikka, M.: Diurnal variations in the UV albedo of arctic snow, Atmos. Chem. Phys., 8, 6551-6563, doi:10.5194/acp-86551-2008, 2008.

Meinander, O., Aarva, A., Poikonen, A., Kontu, A., Suokanerva, H., Asmi, E., Neitola, K., Rodriguez, E., Sanchez, R., Mei, M., de Leeuw, G., and Kyrö, E.: Bipolar long-term high temporal resolution broadband measurement system for incoming and outgoing solar UV radiation, and snow UV albedo, at Sodankylä $\left(67^{\circ} \mathrm{N}\right)$ and Marambio $\left(64^{\circ} \mathrm{S}\right)$, Geosci. Instrum. Method. Data Syst. Discuss., doi:10.5194/gi-2015-31, in review, 2016.

Meister, R.: Snow profiling at Weissfluhjoch, International snow science workshop, 27 September-2 October 2009, Davos, Switzerland, 2009.

Melander, G. and Korhonen, V. V.: Uusi lumentiheysmittari, in: Esitelmät ja pöytäkirjat 1922, Suomalainen tiedeakatemia, 39-42, 1923.

Morin, S., Lejeune, Y., Lesaffre, B., Panel, J.-M., Poncet, D., David, P., and Sudul, M.: An 18-yr long (1993-2011) snow and meteorological dataset from a mid-altitude mountain site (Col de Porte, France, $1325 \mathrm{~m}$ alt.) for driving and evaluating snowpack models, Earth Syst. Sci. Data, 4, 13-21, doi:10.5194/essd-4-13-2012, 2012.

Pirinen, P., Simola, H., Aalto, J., Kaukoranta, J.-P., Karlsson, P., and Ruuhela, R.: Climatological statistics of Finland 19812010,Finnish Meteorological Institute reports, 2012.

Rautiainen, K., Lemmetyinen, J., Pulliainen, J., Vehviläinen, J., Drusch, M., Kontu, A., Kainulainen, J., and Seppänen, J.: L-band radiometer observations of soil processes in boreal and subarctic environments, IEEE T. Geosci. Remote, 50, 1483-1497, 2012.

Rautiainen, K., Lemmetyinen, J., Schwank M., Kontu, A., Menard, C. B., Mätzler, C., Drusch, M., Wiesmann, A., Ikonen, J., and Pulliainen, J.: Detection of soil freezing from L-band passive microwave observations, Remote Sens. Environ., 147, 206-218, 2014.
Rutter, N., Sandells, M., Derksen, C., Toose, P., Royer, A., Montpetit, B., Langlois, A., Lemmetyinen, J., and Pulliainen, J.: Snow stratigraphic heterogeneity within ground-based passive microwave radiometer footprints: Implications for emission modeling, J. Geophys. Res. Earth Surf., 119, 550-565, 2014.

Salminen, M., Pulliainen, J., Metsämäki, S., Kontu, A., and Suokanerva, H.: The behaviour of snow and snow-free surface reflectance in boreal forests: Implications to the performance of snow covered area monitoring, Remote Sens. Environ., 113, 907-918, 2009.

Schwank, M., Wiesmann, A., Werner, C., Mätzler, C., Weber, D., Murk, A., Völksch, I., and Wegmüller, U.: ELBARA II, an Lband radiometer system for soil moisture research, Sensors, 10, 584-612, 2010.

Schwank, M., Rautiainen, K., M’tzler, C., Sahli, M., Lemmetyinen, J., Pulliainen, J., Vehviläinen, J., Kontu, A., Ikonen, J., Menard, C. B., Drusch, M., wiesmann, A., and Wegmüller, U.: Model for microwave emission of a snow-covered ground with focus on L band, Remote Sens. Environ., 154, 180-191, 2014.

Sihvola, A. and Tiuri, M.: Snow fork for field determination of the density and wetness profiles of a snow pack, IEEE T. Geosci. Remote, GE-24, 717-721, 1986.

Sturm, M. and Holmgren, J.: A seasonal snow cover classification system for local to global applications, J. Climate, 8, 1261-1283, 1995.

Sukuvaara, T., Mäenpää, K., and Ylitalo, R.: Vehicular networking and road weather related research in Sodankylä, Geosci. Instrum. Method. Data Syst. Discuss., doi:10.5194/gi-2015-23, in review, 2016.

SYKE: Hydrologisen seurannan ryhmä: Hydrologisen seurannan kenttätöiden toimintakäsikirja (Handbook of field work of hydrological monitoring), available at: http://www.ymparisto.fi/download/noname/, 2015 (in Finnish).

SYKE database: http://www.syke.fi/openinformation, last access: 11 May 2016.

Tietäväinen, H., Tuomenvirta, H., and Venäläinen, A.: Annual and seasonal mean temperatures in Finland during the last 160 years based on gridded temperature data, Int. J. Climatol., 30, 2247 2256, 2010.

Törmä, M., Haakana, M., Hatunen, S., Härmä, P., Kallio, M., Katila, M., Kiiski, T., Mäkisara, K., Peräsaari, J., Piepponen, H., Repo, R., Teiniranta, R., and Tomppo, E.: Finnish Corine 2006 project: determining changes in land cover in Finland between 2000 and 2006, Proc. SPIE 7110, Remote Sensing for Environmental Monitoring, GIS Applications, and Geology VIII, 71100V, doi:10.1117/12.800148, 2008.

van Dijk, A. I. J. M., Renzullo, L. J., Wada, Y., and Tregoning, P.: A global water cycle reanalysis (2003-2012) merging satellite gravimetry and altimetry observations with a hydrological multi-model ensemble, Hydrol. Earth Syst. Sci., 18, 2955-2973, doi:10.5194/hess-18-2955-2014, 2014.

Zuanon, N.: IceCube, a portable and reliable instruments for snow specific surface area measurement in the field, International Snow Science Workshop Grenoble-Chamonix MontBlance-2013 proceedings, 1020-1023, 2013. 